\title{
TEPUNG KEPALA UDANG SEBAGAI SUMBER PROTEIN HEWANI DALAM RANSUM KEPITING BAKAU, Scylla serrata Forsk.
}

\author{
Neltje N. Palinggi ${ }^{*}$, Naftali Kabangnga ${ }^{*}$, dan Dalfiah ${ }^{*}$
}

\begin{abstract}
ABSTRAK
Penelitian dilakukan untuk mengetahui pengaruh perbedaan pemberian bahan baku sumber protein hewani terhadap pertumbuhan dan sintasan benih kepiting bakau (Srylla serrata Forsk.) dalam laboratorium. Perlakuan terdiri dari tiga ulangan dalam rancangan acak lengkap (RAL) dengan perlakuan dua jenis bahan baku sumber protein hewani yaitu tepung ikan dan tepung kepala udang. Masing-masing jenis bahan baku ini ditambah jenis bahan lainnya yang diramu menjadi pakan yang mengandung protein 30 persen. Pakan diberikan sekali sehari sebanyak lima persen dari bobot tubuh.

Hasil penelitian menunjukkan bahwa pemberian kedua jenis pakan tidak memberikan pengaruh pada pertambahan bobot biomassa benih kepiting bakau yang nilai rata-ratanya $7,85 \mathrm{~g}$. demikian pula pada sintasannya (rata-rata 87\%). Berdasarkan hasil tersebut tepung kepala udang dapat menggantikan tepung ikan sebagai sumber protein hewani dalam pakan benih kepiting bakau.
\end{abstract}

\begin{abstract}
Shrimp head meal as an animal protein source for feed mangrove crab, Scylla serrata Forsk. By: Neltje N. Palinggi, Naftali Kabangnga and Dalfiah.
\end{abstract}

\begin{abstract}
The experiment was conducted in order to examine the effect of different animal protein sources on the growth and survival rate of mangrove crab (Scylla serrata Forsk.) under laboratory condition. This experiment used completely randomized design with two treatments and three replicates each. Two experimental diets used in this experiments were fish meal and shrimp head meal. The diet supplied to the tested crab contained $30 \%$ protein and was given at $5 \%$ of body weight per day. The result of the study showed that the diets did not affect the growth and survival rate. It can be concluded that the shrimp head meal can substitute fish meal as animal protein resoures for mangroue crab.
\end{abstract}

KEYWORDS: shrimp head meal, mangrove crab, animal protein feed.

\section{PENDAHULUAN}

Kepiting bakau (Scylla serrata Forsk.) merupakan salah satu hasil perikanan pantai yang mempunyai nilai ekonomis penting dan potensial untuk dibudidayakan. Aspek kebutuhan nutrisi kepiting bakau dalam mendukung kegiatan budidaya menjadi hal yang utama dalam kegiatan penelitian ini.

Halver (1976) mengemukakan bahwa protein merupakan salah satu nutrien yang diperlukan oleh ikan untuk pertumbuhan. Kebutuhan protein pakan berbeda setiap stadia. Pada stadia larva dan benih dibutuhkan protein pakan yang tinggi, tetapi rendah pada stadia pembesaran (Lovell, 1980).

Bahan baku yang digunakan dalam pembuatan pakan seperti tepung ikan, bungkil kedele, tepung cumi, vitamin dan lain-lain sebagian besar adalah bahan pakan impor. Untuk mengatasi hal tersebut perlu penyediaan bahan baku dalam negeri. Di antara beberapa bahan produk lokal yang sudah digunakan dalam pakan ternak dan diperkirakan dapat digunakan dalam pakan kepiting adalah tepung kepala udang. Kepala udang merupakan limbah cold storage yang susah penanganannya karena sifatnya yang cepat membusuk sehingga diperlukan upaya untuk dapat

Peneliti pada Balai Penelitian Perikanan P'antai 
mengelolanya lebih awal. Salah satu upaya yang dapat dilakukan untuk memanfaatkan limbah cold storage ini adalah dengan membuatnya jadi tepung yang selanjutnya dapat digunakan sebagai sumber protein dalam pakan ternak atau ikan.

Penelitian ini bertujuan untuk mengetahui bahan baku sumber protein yang dapat menggantikan tepung ikan dalam pakan kepiting bakau.

\section{BAHAN DAN METODE}

Penelitian dilakukan di laboratorium basah Balitkanta selama 50 hari (April-Mei 1995). Wadah berupa serat gelas ukuran $1 \times 1 \times 0,6 \mathrm{~m}^{3}$, sebanyak enam buah diisi air laut masing-masing 400 liter dan dilengkapi dua titik aerasi. Ke dalam setiap wadah dimasukkan sembilan buah keranjang plastik berisi pasir yang masingmasing keranjang diisi satu ekor benih kepiting dengan bobot, panjang dan lebar karapas ratarata $20,61 \mathrm{~g}, 3,3 \mathrm{~cm}$ dan $4,8 \mathrm{~cm}$. Penggunaan keranjang plastik dalam setiap bak dimaksudkan agar tidak terjadi kematian akibat kanibalisme. Pergantian air dilakukan setiap hari setelah penyiponan sisa pakan dan feses sebanyak air yang dikeluarkan. Sebelum penelitian, dilakukan adaptasi benih terhadap pakan dan air media selama satu minggu.

Percobaan dilakukan dalam rancangan acak lengkap (RAL). Perlakuan adalah dua jenis bahan baku sumber protein hewani yang terdiri atas tepung ikan, dan tepung kepala udang. Tiap perlakuan diulang tiga kali. Masing-masing jenis bahan baku ini dicampur dengan beberapa jenis bahan lainnya yang kemudian diramu berdasar. kan hasil analisis proksimatsi setiap bahan baku (Tabel 1), sehingga diperoleh pakan yang mengandung protein 30 persen (Tabel 2). Pakan diberikan dalam bentuk pellet sekali dalam sehari sebanyak lima persen dari bobot tubuh. Perubahan jumlah pakan dilakukan setiap 10 hari setelah selesai penimbangan dan disesuaikan dengan perubahan bobot tubuh kepiting bakau.

Pengamatan pengaruh perlakuan terhadap pertumbuhan dilakukan setiap 10 hari dengan menggunakan timbangan elektrik merek AND berketelitian $0,1 \mathrm{~g}$ (untuk bobot) dan meteran kain berketelitian $0,1 \mathrm{~cm}$ (untuk panjang dan lebar karapas). Pengamatan pergantian kulit dilakukan setiap hari untuk mengetahui frekuensi pergantian kulit selama penelitian. Perhitungan pertumbuhan dilakukan berdasarkan rumus Effendi (1979), sedang sintasan berdasarkan rumus Sedgwik (1979). Pemantauan terhadap beberapa peubah kualitas air seperti suhu (dengan thermometer), $\mathrm{pH}$ ( $\mathrm{pH}$ indicator universal), salinitas (refraktometer ATAGO) dan oksigen terlarut (DO meter) dilakukan setiap hari, sedang amonia (spectrophotometer), nitrit (spectrophotometer) dan bahan organik terlarut (volumeoksidimetri) dilakukan setiap 10 hari.

Data pertumbuhan dianalisis dengan bantuan paket program statistik dan dilanjutkan dengan Uji Tukey untuk mengetahui pengaruh perbedaan antar perlakuan.

Tabel 1. Kandungan nutrisi bahan baku sumber protein.

Table 1. Composition of nutrient of different protein sources.

\begin{tabular}{lcccc}
\hline \multicolumn{2}{c}{$\begin{array}{c}\text { Komposisi } \\
\text { Composition }\end{array}$} & $\begin{array}{c}\text { Tepung ikan } \\
\text { Fish meal }\end{array}$ & $\begin{array}{c}\text { Tepung kepala udang } \\
\text { Shrimp head meal }\end{array}$ & $\begin{array}{c}\text { Tepung kedelai } \\
\text { Soybean meal }\end{array}$ \\
\hline Protein & $(\%)$ & 56.04 & 42.16 & 43.24 \\
Lemak (Fat) & $(\%)$ & 5.53 & 2.93 & 2.61 \\
Air (Moisture) & $(\%)$ & 0.16 & 10.02 & 20.05 \\
Abu (Ash) & $(\%)$ & 29.53 & 25.41 & 7.98 \\
\hline
\end{tabular}


Tabel 2. Komposisi pakan yang digunakan dalam penelitian.

Table 2. Composition of feed fed to mangrove crab used during the experiment.

\begin{tabular}{|c|c|c|}
\hline \multirow[b]{2}{*}{$\begin{array}{c}\text { Bahan } \\
\text { Ingredient }\end{array}$} & \multicolumn{2}{|c|}{ Diet (Diet) } \\
\hline & $\begin{array}{l}\text { Tepung ikan } \\
\text { Fish meal }\end{array}$ & $\begin{array}{l}\text { Tepung kepala udang } \\
\text { Shrimp head meal }\end{array}$ \\
\hline Tepung ikan (Fish meal) (\%) & 39.1 & - \\
\hline Tepung kepala udang (Shrimp head meal) (\%) & - & 44.9 \\
\hline Tepung kedelai (Soybean meal) (\%) & 20.1 & 22.8 \\
\hline Tepung beras (Rice bran) $(\%)$ & 31.8 & 23.3 \\
\hline Stark $($ Starch $)(\%)$ & 7 & 7 \\
\hline $\begin{array}{l}\text { Vitamin dan campuran mineral (Vitamin and } \\
\text { mineral mix.) (\%) }\end{array}$ & 2 & 2 \\
\hline Protein (\%) & 30.08 & 30.06 \\
\hline Lemak (Lipid) $(\%)$ & 3.79 & 4.26 \\
\hline Abu $(A s h)(\%)$ & 6.21 & 6.54 \\
\hline Serat (Fiber) $(\%)$ & 8.47 & 8.42 \\
\hline Enersi (Energy) (cal/g) & $2,264.59$ & $2,265.03$ \\
\hline
\end{tabular}

\section{HASIL DAN PEMBAHASAN}

Selama penelitian berlangsung terjadi pertam. bahan bobot badan, panjang dan lebar karapas pada setiap perlakuan (Tabel 3). Pertumbuhan individu kepiting bakau mengikuti pola pertumbuhan eksponensial positif (Gambar 1) dengan pertambahan bobot rata-rata untuk perlakuan tepung ikan 8,58 g serta tepung kepala udang $7,13 \mathrm{~g}$, di mana analisis ragam memperlihatkan perbedaan yang tidak nyata $(P>0,05)$. Hal ini mungkin disebabkan karena kepala udang adalah bahan baku dari jenis krustase yang mempunyai komposisi nutrien yang mirip dan dibutuhkan oleh kepiting bakau. Selain itu, kedua bahan baku ini adalah sumber protein hewani yang mempunyai komposisi asam amino yang mirip dan dibutuhkan oleh kepiting bakau untuk hidup dan bertumbuh. Hal ini ditunjang oleh Pascual (1984) yang mengemukakan bahwa protein dari bahan hewani mempunyai komposisi asam amino yang lebih baik dari bahan nabati. Selanjutnya Arthur dan Philips (1979) mengemukakan bahwa nilai protein dari ransum ikan untuk pertumbuhan tergantung pada kualitas protein yang dikandungnya, dan ransum yang paling efisien adalah ransum yang kandungan proteinnya mempunyai asam amino yang kualitas dan kuantitasnya tepat sesuai kebutuhan ikan tersebut.
Pergantian kulit yang terjadi pada kepiting bakau merupakan indikasi adanya proses pertumbuhan somatik yang diatur oleh hormon ganti kulit (moult hormon) yang dihasilkan oleh organ Y. Selain itu pergantian kulit juga ditunjang oleh pakan yang berkualitas, karena proses pergantian kulit membutuhkan energi yang cukup besar yang diperoleh dari pakan. Selama penelitian berlangsung terjadi pergantian kulit dalam waktu yang berbeda dan menghasilkan pertambahan panjang dan lebar karapas seperti yang tertera pada Tabel 3. Pertambahan panjang dan lebar karapas tidak berbeda untuk kedua perlakuan tersebut $(\mathrm{P}>0,05)$. Hal ini memperlihatkan bahwa kualitas tepung ikan dan kepala udang sama untuk memenuhi kebutuhan nutrien bagi pertumbuhan kepiting bakau.

Berdasarkan hasil tersebut dapat disimpulkan bahwa kepala udang dapat menggantikan tepung ikan sebagai sumber protein hewani dalam pakan kepiting bakau. How-Cheong et al. (1991) mengemukakan bahwa bahan pakan yang dapat digunakan sebagai sumber protein dalam pakan kepiting bakau adalah tepung ikan, tepung kepala udang, daging kerang dan tepung kedelai.

Sintasan kepiting bakau pada akhir percobaan tidak dipengaruhi oleh jenis bahan baku yang digunakan $(\mathrm{P}>0,05)$, yaitu masing-masing 77,8 
Tabel 3. Pertumbuhan, sintasan dan pertambahan karapas kepiting bakau.

Table 3. Growth. survival rate and carapace width of mangrove crab.

\begin{tabular}{lccc}
\hline \multirow{2}{*}{$\begin{array}{l}\text { Compositian } \\
\text { Variabel }\end{array}$} & \multicolumn{2}{c}{ Perlakuan (Treatment)* } \\
\cline { 3 - 4 } & & $\begin{array}{c}\text { Tepung ikan } \\
\text { Fish meal }\end{array}$ & $\begin{array}{c}\text { Tepung kepala udang } \\
\text { Shrimp head meal }\end{array}$ \\
\hline Pertambahan bobot (Weight increase) & $(\mathrm{g})$ & 8.58 & 7.13 \\
Tingkat pertumbuhan (Crowth rate) & $(\%)$ & $0.9920^{*}$ & $0.8806^{\mathrm{a}}$ \\
Pertambahan panjang karapas (Carapace & & $0.8^{\mathrm{a}}$ & $0.8^{\mathrm{a}}$ \\
length increase) & $(\mathrm{cm})$ & & $1.1^{\mathrm{a}}$ \\
$\begin{array}{l}\text { Pertambahan lebar karapas (Carapace } \\
\text { width increase) }\end{array}$ & $(\mathrm{cm})$ & $0.9^{a}$ & $96.3^{\mathrm{a}}$ \\
Sintasan (Survival rate) & $(\%)$ & $77.8^{*}$ &
\end{tabular}

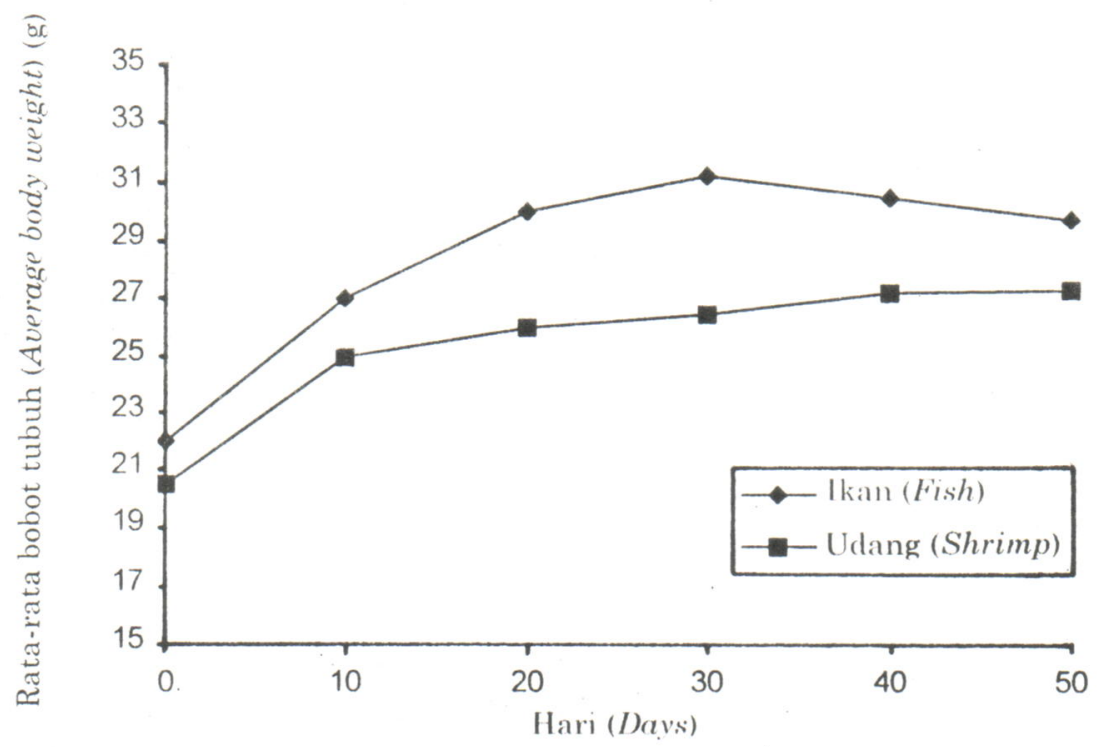

Gambar 1. Bobot rata-rata individu kepiting bakau selama percobaan.

Figure 1. Average weight of mangrove crab during the experiment.

dan $96,3 \%$ untuk pakan sumber protein tepung ikan dan tepung kepala udang.

Suhu air yang diukur selama penelitian berlangsung berkisar $26,8-28,4^{\circ} \mathrm{C}$; $\mathrm{pH}$ air berkisar 7,0-8,5; sedang kandungan oksigen terlarut. amonia dan nitrit yang diukur setiap minggu masing-masing berkisar 5,7-8,7 mg/L; 0,0264. $0,0531 \mathrm{mg} / \mathrm{L} ; 0,0023-0,0084 \mathrm{mg} / \mathrm{L}$. Kualitas air ini masih baik bagi kehidupan dan pertumbuhan kepiting bakau karena setiap hari dilakukan penyiponan sisa pakan dan feses serta penggantian air sebanyak $30 \%$ /hari dan diberi aerasi. Hal ini menunjukkan bahwa derajat pencemaran baik oleh pakan maupun ekskresi kepiting bakau tidak berbeda. Hasil tersebut memperlihatkan bahwa sifat fisik dan kestabilan dalam air (water stability) dari semua pakan adalah sama.

\section{KESIMPULAN}

Dari hasil penelitian ini dapat disimpulkan bahwa tepung kepala udang dapat menggantikan tepung ikan sebagai sumber protein hewani dalam pakan benih kepiting bakau. 


\section{UCAPAN TERIMA KASIH}

Ucapan terima kasih disampaikan kepada Sdr. Reny Yulianingsih, Sutrisyani, Dra. Rosiana Sabang dan Yohanes Teken yang telah membantu dalam penelitian ini baik di laboratorium maupun di lapangan.

\section{DAFTAR PUSTAKA}

Arthur, M. and Philips Jr. 1969. Nutrition, digestion and energy utilization. In Hoar et al. (eds), Fish Physiology. Vol. 1:391-423. Academic Press, New York: 391-423.

Effendie, M.I. 1979. Biologi perikanan, Cetakan I. Penerbit Yayasan Dewi Sri. Bogor.

Halver, J.E. 1976. The nutritional requirement of cultivated warmwater and coldwater fish species. Advance in Aquaculture: 574-580.
How-Cheong, C., U.P.D. Gunasekera and H.P. Amandakoon. 1991. Formulation of artificial feeds for mud crab culture: A preliminary biochemical, physical and biological evaluation. In C.A. Angell. Report of the Seminar on the mud crab Bungal Programme, Madras, India. BOBP/REP/51. GCP/ RAS/118/MUL: 179-184.

Lovell, R.T. 1980. Practical fish diets. In Fish feed technology. United Nation Development Programme, Food and Agriculture Organization of United Nation, Rome: 32-40.

Pascual, F.P. 1984. Nutrient and feeding of sugpo, Penaeus monodon. Journal UNDP/FAO 8(3):77-86.

Sedgwick, R.W. 1979. Influence of dietary protein and energy on growth, food consumption and food conversion efficiency in Penaeus marguiensis de Man. Aquaculture (6):7-30. 